\title{
Nekton communities of an intertidal creek of a European estuarine brackish marsh
}

\author{
Andre Cattrijsse, Esther S. Makwaia, Hederick R. Dankwa, Olivier Hamerlynck, \\ Marten A. Hemminga
}

University of Gent, Zoology Institute, Marine Biology Section, Ledeganckstraat 35, B-9000 Gent, Belgium

and

Netherlands Institute for Ecological Research, Centre for Estuarine and Coastal Ecology, Vierstraat 28, 4401 EA Yerseke, The Netherlands

\begin{abstract}
The utilization of an estuarine brackish marsh in the Westerschelde estuary (southwest Netherlands) by fish and crustaceans visiting the intertidal creeks at rising tides was investigated over an 18 mo period. Samples were collected every month over a tidal cycle. A stow net passively fished the nekton migrating in and out of the marsh habitat. Simultaneous measurements of current speed and waterheight allowed for quantification of the catches. Multivariate clustering and ordination techniques were applied to assess temporal changes in the nekton assemblage. A total of 68 fish and crustacean species were caught but only 38 were regular visitors of the marsh creek. The marsh nekton community proved to have a very stable character. Only $40 \%$ of the observed variance could be explained. The seasonal appearance of juvenile stages of fish and crustaceans was found to differentiate between spring and summer-autumn communities. The environmental variables measured (i.e. temperature, salinity, oxygen concentration and detritus standing stock) did not correlate well with the observed changes in community structure. The mysid shrimp Neomysis integer dominated the community, both in density and biomass, during most of the year. Early postlarval flounder Pleuronectes flesus characterized the spring nekton assemblage. Early postlarval brown shrimp Crangon crangon was abundant from spring through autumn. In late summer juveniles of seabass Dicentrarchus labrax, common goby Pomatoschistus microps and shore crab Carcinus maenas were typical members of the marsh creek nekton. The hyperbenthic fauna of the marsh was comparable to the hyperbenthos found in the adjacent subtidal parts of the Westerschelde estuary while the epifauna of both areas differed substantially. It is argued that the marsh under study is a nursery ground for only a small number of estuarine inhabitants: C. crangon, P. flesus, C. maenas, P. microps, D. labrax and possibly 2 mullet species. Adult flounder, adult and juvenile common goby, juvenile seabass and the early postlarval brown shrimp all use the creeks as feeding ground, mainly preying upon the creek infauna and mysids. Given the high abundance of hyperbenthic mysid shrimp in the marsh and their presumed role in detritus-based food chains, we believe marsh studies should not refrain from considering this component of the nekton. This is the first study reporting on the nekton use of a European marsh. The need for similar research in other European marshes is stressed.
\end{abstract}

KEY WORDS: Westerschelde $\cdot$ Tidal marsh $\cdot$ Creek habitat $\cdot$ Nekton communities

\section{INTRODUCTION}

Wetlands, such as mangroves and salt marshes, are important nursery areas and feeding grounds for fishes and macrocrustaceans (Boesch \& Turner 1984). In this respect an extensive literature has been established about the North American salt marshes, paralleled by investigations in mangroves. In Europe little or no attention has been paid to the nursery role or feeding ground value of tidal marshes. To date, zoological studies in European marshes have only focused on the terrestrial component or concerned the infauna (Daiber 1982, Dijkema et al. 1984). The nekton communities using the intertidal marsh creeks have rarely been studied and the role these habitats play for fishes or macrocrustaceans remains largely uninvestigated. 
Labourg et al. (1985) have published some preliminary results on the occurrence of juvenile fish in shallow habitats associated with marsh areas. Frid (1988) and Frid \& James (1989) have reported on the nekton of European coastal marshes. Still, these studies focused mainly on marsh pools and data about the use of tidal creeks are fragmentary. More recently Drake \& Arias (1991) described the ichthyoplankton of tidal channels in the south of Spain and evaluated the nursery function of these shallow areas. Mees et al. (1993a) reported briefly on the use of estuarine marshes by mysid shrimp, while the hyperbenthic amphipod and isopod faunas present in estuarine marsh creeks were described by Cattrijsse et al. (1993).

Within the intertidal zone, North American Atlantic salt-marsh vegetations do not occur lower than Mean High Water Neap tide (MHWN) (Reimold 1977), while in Europe mean tidal level (MTL) borders the low marsh (Beeftink 1977). As a consequence the vegetated surface of European marshes, in contrast to that of American marshes, is usually only flooded for a short period during relatively high spring tides. Fish and crustaceans will thus nearly always be restricted to the intertidal creeks. The refuge offered by submerged vascular plants as found for the North American marshes (Minello \& Zimmerman 1983, Kneib 1987, Rozas \& Odum 1988) will be minimal or nonexistent. The utilization of European marsh habitats by fish and macrocrustaceans may therefore differ in at least this aspect from the American situation.

The studied marsh lies in the brackish part of the Westerschelde estuary (SW Netherlands) which forms the gate to the harbour of Antwerp (Fig. 1). It is a heavily polluted area (Van Eck et al. 1991) almost completely disposed of its marshes due to land reclamation (Huiskes 1988). The Westerschelde fulfils a nursery role, although to a lesser extent than the Wadden Sea and the coastal shallows of the southern North Sea, even though densities of juvenile fish, shrimp and crabs are considerable (Zijlstra 1972, de Veen et al. 1979, Van Beek \& Boddeke 1990). The various components of the estuarine ecosystem are well documented (Heip 1988) but the utilization of the intertidal areas by fish and macrocrustacean remain unexplored.

The goal of this study was to investigate the utilization of marsh creeks by the estuarine mobile epifauna and hyperbenthic fauna. Both components are referred to as nekton. With hyperbenthos (mysids, amphipods, isopods) we targeted all actively migrating animals who live in close proximity to the bottom (less than $1 \mathrm{~m}$ ), but not on the bottom, and are larger than $1 \mathrm{~mm}$ (Mees et al. 1993b). The nekton communities visiting the intertidal creek of an estuarine salt marsh are defined. The temporal changes happening in the community structure and their relation with environmental variables are examined. The nursery and feeding ground values for estuarine fish and crustaceans are evaluated.

\section{MATERIALS AND METHODS}

Study site. Sampling was done in the tidal marsh 'Het Verdronken Land van Saeftinghe' close to the Dutch-Belgian border a few kilometres downstream from the harbour of Antwerp (Fig. 1). The marsh is situated in the brackish reaches on the left bank of the Westerschelde estuary, close to the main subtidal channel. With a surface area of $27.69 \mathrm{~km}^{2}$ it is one of the largest estuarine brackish marshes left in Europe (Dijkema et al. 1984). Mean tidal range at the study site is about $3 \mathrm{~m}$ and the salinity of the adjacent estuarine waters varies on average between 10 and $15 \%$. Data on marsh vegetation in the southwest Netherlands were reported by Beeftink $(1966,1977)$.

All samples were taken in a creek on the east side of the marsh (Fig. 1). Scirpus maritimus, Triglochin maritima, Puccinellia maritima, Elymus athericus, Phragmites australis and Atriplex hastata are the dominant marsh plants growing in the drainage area of the creek (Hemminga et al. 1993). This creek runs perpendicular to the estuarine channel. The total length of the creek is ca $1600 \mathrm{~m}$, it is $36 \mathrm{~m}$ wide and has a depth of $4 \mathrm{~m}$ at the sampling point. It floods and drains a marsh surface of approximately 75 ha. There is no connection to any other major creek on the marsh. The total creek and marsh surface behind the sampling point were estimated to be about 2 and 50 ha respectively. Every tidal cycle the creek falls completely dry for at least $5 \mathrm{~h}$. Water starts entering the system about $3 \mathrm{~h}$ before high tide and leaves the creek within $4 \mathrm{~h}$ after. This asymmetry in the tidal flooding is a typical feature of marshes in the whole area. Current speed peaks in the first hour of ebb (Fig. 2). After the flooding a small channel with slowly running seepage water remains with a depth of a few centimetres and a breadth of $1 \mathrm{~m}$.

Sampling. Monthly samples were taken from March 1990 through October 1991. Adverse weather conditions prevented us from sampling in September 1990 , February 1991 and November 1991. Samples were taken with a fyke net modified after Mclvor \& Odum (1986). The netting material was polyamide gauze with a mesh of $1 \mathrm{~mm}$ and an opening of $1 \times 1 \mathrm{~m}$. The length of the net was calculated to be $4 \mathrm{~m}$ in order to keep the pressure wave inside the net under all conditions (Tranter 1979). An extra $1 \mathrm{~m}$ was added to take into account clogging of the net with decaying plant material. In the cod end a meshed funnel prevented escape of animals. An iron chain kept the ground rope along the bottom. The net was mounted on a metal frame, 

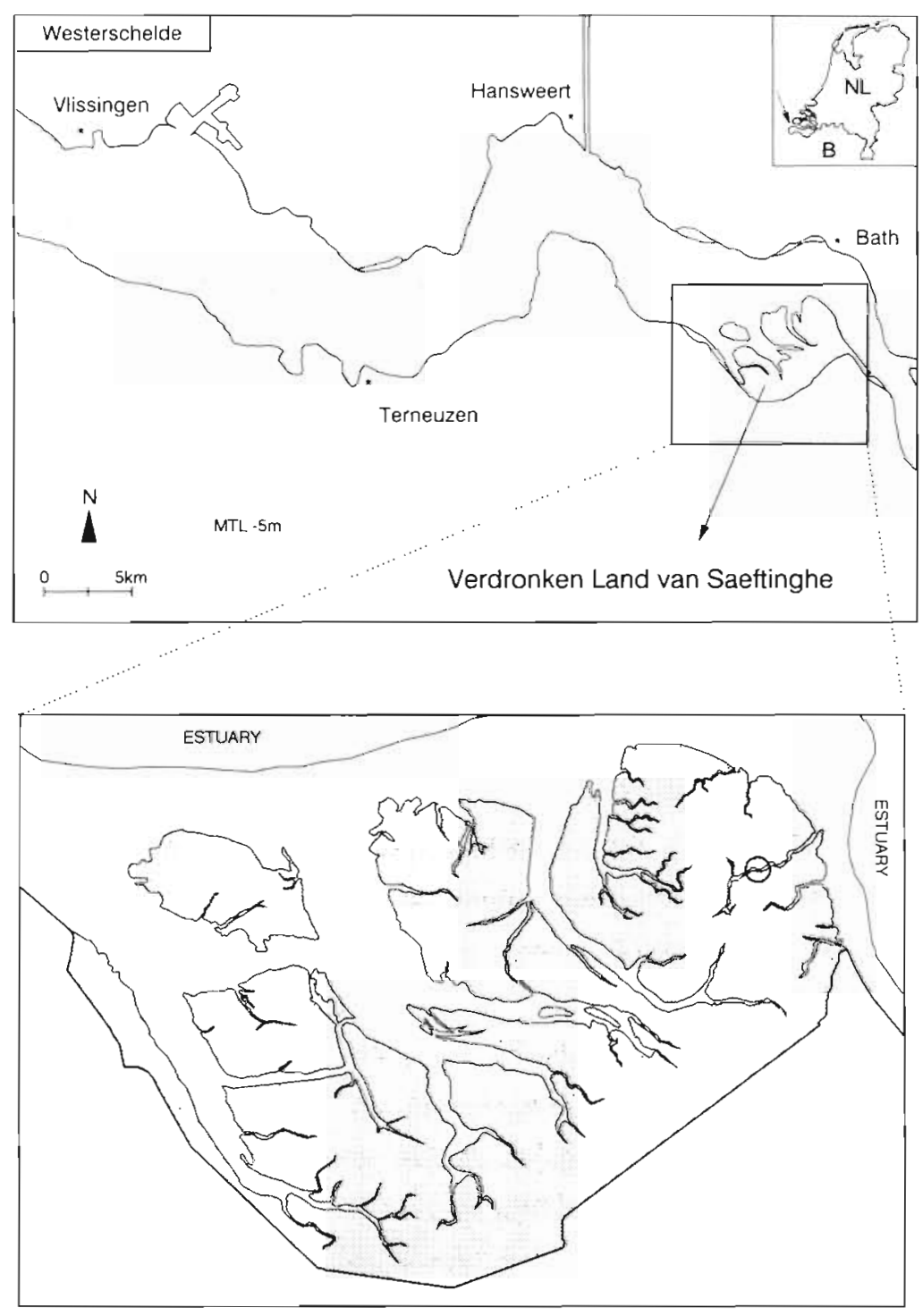

Fig. 1. Study area in the Westerschelde estuary, SW Netherlands, showing the marsh and its position in the estuary. The sampling point is circled

During sampling, the current speed and the height of the water were measured every 15 min. Water height was measured with a ruled stake placed near the net in the deepest part of the creek. Current speed was measured with an OTT-mill current meter, positioned about $20 \mathrm{~cm}$ above the bottom close to the net. Four consecutive $1 \mathrm{~min}$ readings were averaged to estimate the current velocity. Oxygen concentration, salinity and temperature of the water were measured hourly. Samples were preserved in a $10 \%$ formalin seawater solution. When necessary volumetric subsamples were taken, as most of the catches contained considerable amounts of decaying plant material.

In the laboratory, all species were identified to species level, counted and measured to the nearest $\mathrm{mm}$. Standard lengths of fish, shrimp and mysids and carapace widths for crabs were recorded. For shrimp and mysids standard lengths were defined as the length from the anterior end of the carapace (excluding the rostrum) to the posterior end of the last abdominal segment (excluding the telson). Fish, adult shrimp and crabs were measured with a ruler. Lengths of all other organisms, a maximum of 30 individuals per sample, were drawn under a dissecting microscope with the aid of a drawing mirror. The decaying plant material trapped inside the net was oven dried at $60^{\circ} \mathrm{C}$ for $3 \mathrm{~d}$ and weighed.

Data processing and analysis. In order to quantify the catches, the volume of water filtered by the gear and

operated from upon a bridge and placed on the creek bottom. Two weights were attached at the sides of the frame and ropes kept the net in place while fishing. The net was placed in the centre of the creek where 2 evenly sloping banks were present as bank geomorphology influences nekton distributions (McIvor \& Odum 1988).

Sampling was started when water began to flood the creek, the net opening facing the flood current. After slack water the net was turned around to sample the ebb current. The net was hauled every hour, rinsed and placed back in the same position. Samples were taken around spring tide generally yielding 3 flood samples and 4 ebb samples. The May 1991 sampling was delayed and occurred a few days later than spring tide. the volume of water passing through the creek were estimated at intervals of $15 \mathrm{~min}$. First, the cross-sectional area for every possible water height at the sampling point was measured. Height, current and crosssection allowed for the calculation of the flow $\left(\mathrm{m}^{3} \mathrm{~s}^{-1}\right)$ at the sampling point. Current, water height and consequently cross-sectional area and flow were assumed to be constant over the $15 \mathrm{~min}$ period. Summing the water volumes of 4 intervals yielded the total volume for $1 \mathrm{~h}$ of sampling. Only the lower metre of the water column was considered for calculating total abundance, density and biomass.

Densities of the incoming and the outgoing water volumes were calculated for each hourly sample (no. $\mathrm{m}^{-3}$ ). Both the cumulative densities of the flood sam- 


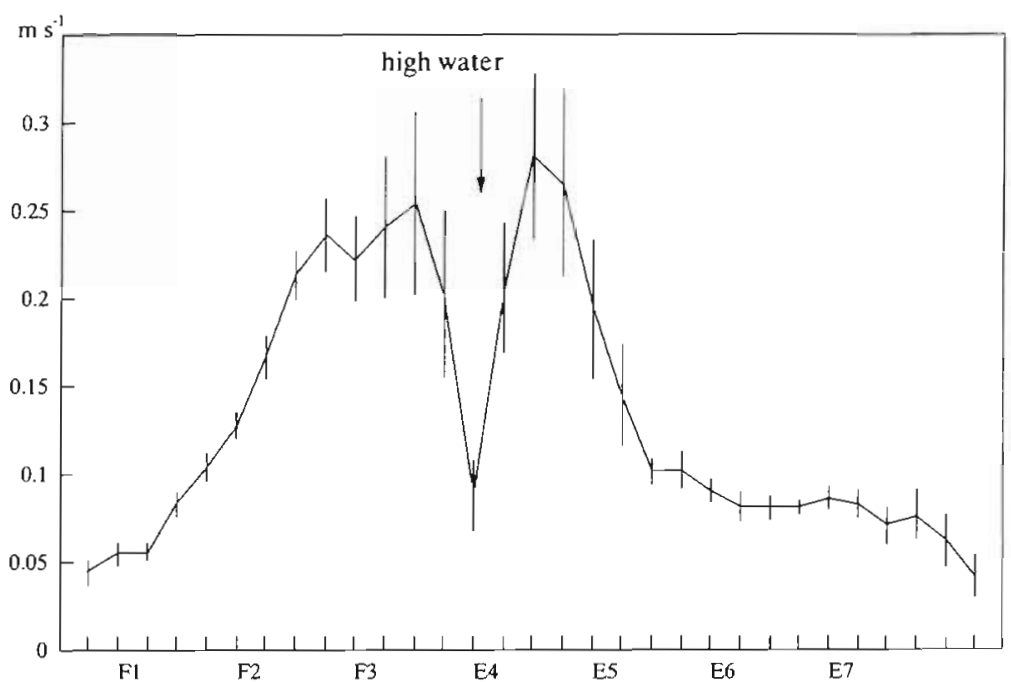

Fig. 2. Current speed $\left(\mathrm{m} \mathrm{s}^{-1}, \pm 1 \mathrm{SE}\right)$ over the tidal cycle as measured at $15 \mathrm{~min}$ intervals during sampling. Flood samples denoted as F1 to F3, ebb samples as E4 to E7

ples and the tidal flood volume were used to estimate an overall abundance present on the marsh at the moment of high water. The same procedure with the 4 ebb samples provided another estimate of the densities present at high water. Both results were subsequently averaged and used as the reported density for a particular sampling date. The same procedure was followed to calculate biomass (mg ADW m $\mathrm{m}^{-3}$ ) which was computed with length-ADW regressions found in the literature (Hamerlynck et al. 1990) or established in the laboratory (A. Cattrijsse, K. Hostens \& J. Mees unpubl. data).

Most of the shrimp caught in the tidal creek were no larger than $10 \mathrm{~mm}$ (postlarvae). As these early developmental stages have a different ecology they were treated as a separate 'species'. Following the same reasoning juvenile glass eels Anguilla anguilla, early postlarval flounder Pleuronectes flesus ( $<15 \mathrm{~mm} \mathrm{SL}$ ), and both zoea and megalopa larvae of Carcinus maenas were treated as ecospecies.

Prior to analysis, jellyfish, larvae of macrobenthic organisms and polychaete worms were excluded from the data matrix as they were not considered representative of the targeted epifauna and hyperbenthos. Field et al. (1982) proposed to exclude the rare species contributing less than $4 \%$ to the total density or biomass. Applying this rule of thumb would have severly reduced our data set and would have caused too much loss of information. To stabilise programme outcomes, we opted to omit the rare species, i.e. those found less than 3 times throughout the study period. Only 38 species were used in constructing the data matrices employed in the multivariate analyses (Table 1). Density and biomass data were 4 throot transformed prior to analyses. The communities were identified with the aid of several independent multivariate techniques (Field et al. 1982). All samples

Table 1. Fish and crustacean species used in the construction of the data matrices and their abbreviations used in the CCA plots

\begin{tabular}{|c|c|c|c|}
\hline \multicolumn{2}{|l|}{ Pisces } & \multicolumn{2}{|l|}{ Crustacea } \\
\hline Anguilla anguilla glass eels & Angu Juve & Crangon crangon & Cran cran \\
\hline Clupea harengus & Clup hare & Crangon crangon postlarvae & Cran Post \\
\hline Sprattus sprattus & Spra spra & Palaemonetes varians & Pala vari \\
\hline Clupeidae larvae & Clup Larv & Palaemon elegans & Pala eleg \\
\hline Gasterosteus aculeatus & Gast acul & Carcinus maenas & Carc maen \\
\hline Syngnathus rostellatus & Syng rost & Carcinus maenas zoeae & Carc Zoea \\
\hline Dicentrarchus labrax & Dice labr & Carcinus maenas megalopae & Carc Mega \\
\hline Chelon labrosus & Chel labr & Neomysis integer & Neom inte \\
\hline Pomatoschistus microps & Poma micr & Mesopodopsis slabberi & Meso slab \\
\hline Pomatoschistus minutus & Poma minu & Praunus flexuosus & Prau flex \\
\hline Pomatoschistus lozanoi & Poma loza & Gastrosaccus spinifer & Gast spin \\
\hline Pomatoschistus species & Poma Spec & Gammarus salinus & Gamm sali \\
\hline Pleuronectes platessa postlarvae & Pleu plat & Gammarus zaddachi & Gamm zadd \\
\hline Pleuronectes flesus & Pleu fles & Orchestia gammarellus & Orch gamm \\
\hline Pleuronectes flesus postlarvae & Pleu Post & Corophium volutator & Coro volu \\
\hline Solea solea postlarvae & Sole sole & Corophium lacustre & Coro lacu \\
\hline Fish larvae (unidentified) & Fish larv & Bathyporeia species & Bath Spec \\
\hline & & Pleusymtes glaber & Pleu glab \\
\hline & & Eurydice pulchra & Eury pulc \\
\hline & & Lekanesphaera rugicauda & Leka rugi \\
\hline & & Paragnathia formica & Para form \\
\hline
\end{tabular}


were first classified according to species composition with the TWINSPAN programme (Hill 1979). The cutlevels used in the analysis were $0.0,0.22,0.44$ and 0.75 for the density data and $0.0,0.32,0.83$ and 1.27 for the biomass data respectively. A cluster analysis based upon Bray-Curtis similarities, using group-average sorting, was employed to check the classifications made by TWINSPAN. Finally, the relationship of the communities with environmental variables was verified using Canonical Correspondence Analysis as laid out by the CANOCO programme (ter Braak 1988). Abbreviated species names as used in this analysis and the corresponding figures are represented in the species list in Table 1.

\section{RESULTS}

The environmental variables measured are represented in Fig. 3. Only temperature and salinity showed clear and positively correlated seasonal trends with each other. Temperature peaked in August 1990 and 1991 with values of 22 and $23^{\circ} \mathrm{C}$ respectively. The lowest value was found in January 1991 when water temperature was only $6^{\circ} \mathrm{C}$. Maximum salinity values were reached at the end of the summer when precipitation was low and evaporation high. A maximum of $16.1 \%$ was recorded in August 1990 and the minimum value of $3.4 \%$ was found in January 1991. The oxygen concentration fluctuated heavily during both years with a minimum of $2.3 \mathrm{mg} \mathrm{l}^{-1}$ in March 1990 and a maximum of $5.5 \mathrm{mg}^{-1}$ in January 1991 . The amount of detritus was lower during spring and started to increase from July onwards. In July 1990 and January 1991 the amount of detritus in the watercolumn exceeded $0.15 \mathrm{~g}$ $\mathrm{m}^{-3}$. The salt-marsh vegetation had by then reached its maximum standing crop and most plants had started to die off. The total amount of decaying plant material was much lower during 1991 when values never exceded $0.05 \mathrm{~g} \mathrm{~m}^{-3}$. The water level in the creek was used as a variable expressing differences which may occur during separate tidal phases. In May 1991, the sampling took place a few days after spring tide and the water level reached a hight of only $270 \mathrm{~cm}$ in the creek. In April 1990 and 1991 water levels reached a maximum of $390 \mathrm{~cm}$.

A total of 68 species were captured with the fyke net during the 2 yr of study. Almost half of these were rare or caught only occasionally, leaving 38 species as common or regularly present in the creeks (Table 1). The mysids Neomysis integer and Mesopodopsis slabberi, the caridean shrimp Crangon crangon (postlarvae and adults), the palaemonid shrimp Palaemonetes varians, the amphipods Corophium volutator, Gammarus salinus, G. zaddachi and Orchestia gammarellus, the iso-
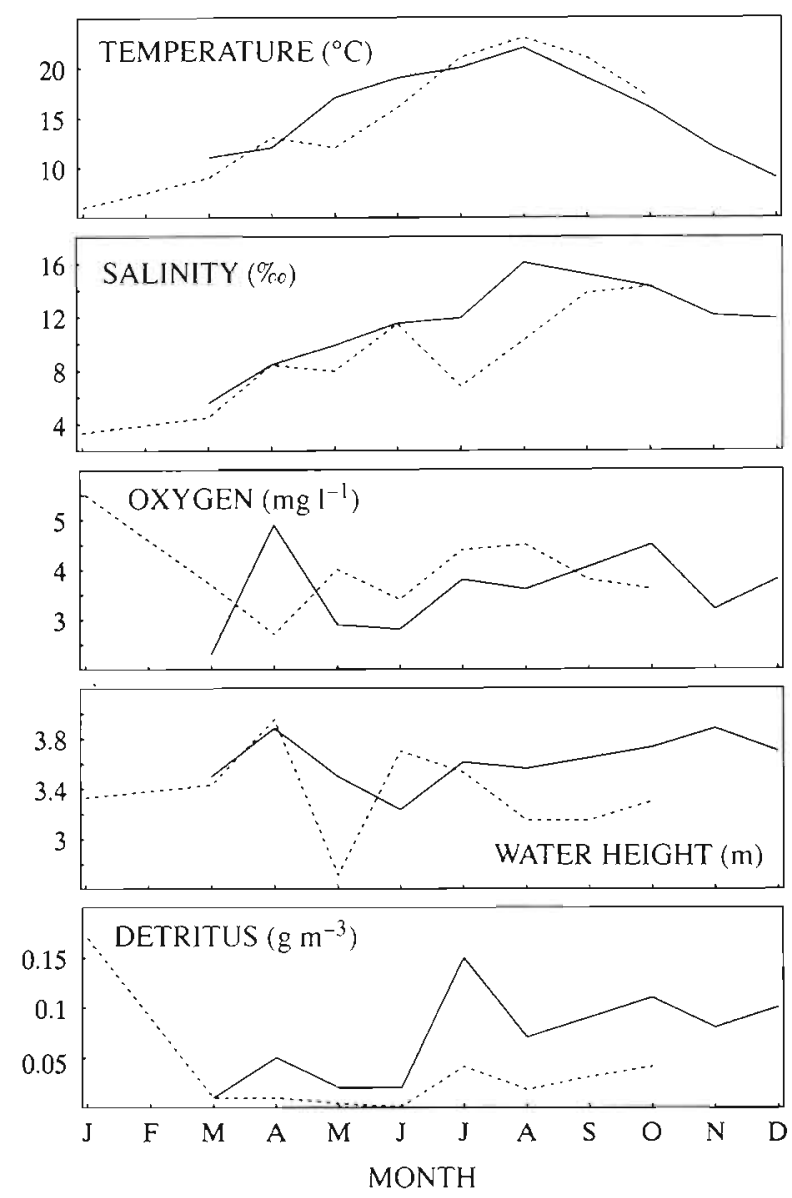

Fig. 3. Seasonal variation of temperature, salinity, oxygen concentration, water height at the sampling point and detritus density of the lower metre of the water column. (-) 1990 data; $(--) 1991$ data

pods Eurydice pulchra, Lekanesphaera rugicauda and Paragnathia formica, the shore crab Carcinus maenas and the fishes Pomatoschistus microps, Dicentrarchus labrax, Pleuronectes flesus and Syngnathus rostellatus were the only species present in at least half of the sampled months. Densities (ind. $\mathrm{m}^{-3}$ ) for the most important species are represented in Table 2 and biomasses ( $\mathrm{mg} \mathrm{ADW} \mathrm{m}^{-3}$ ) in Table 3. For comparative purposes we also listed densities per unit area.

Some of these species cannot be considered true members of the fauna migrating in and out of the marsh creek. Especially concerning Corophium volutator and Orchestia gammarellus a problem arises. $C$. volutator is a typical member of the infauna although it is known to swim frequently (Hughes 1988). O. gammarellus is a semiterrestrial amphipod which reaches very high abundances amongst litter on the marsh surface during late summer.

In most months the mysid shrimp Neomysis integer outnumbered all other species of the community 
Table 2. Densities for the most important fish and crustacean species using the marsh creeks as nursery and for both mysid species. Area: ind. $100 \mathrm{~m}^{-2}$; Vol.: ind. $\mathrm{m}^{-3}$ Note that the conversion to densities per unit area differs as total water volumes depend on tidal phase

\begin{tabular}{|c|c|c|c|c|c|c|c|c|c|}
\hline 1990 & $15 \mathrm{Mar}$ & $11 \mathrm{Apr}$ & $10 \mathrm{May}$ & $11 \mathrm{Jun}$ & $9 \mathrm{Jul}$ & 8 Aug & $10 \mathrm{Oct}$ & $5 \mathrm{Nov}$ & $3 \mathrm{Dec}$ \\
\hline \multicolumn{10}{|c|}{ Dicentrarchus labrax } \\
\hline Area & 0.43 & 0.51 & 0.15 & 1.43 & 3.35 & 3.07 & 2.94 & 2.04 & 0.57 \\
\hline Vol. & 0.004 & 0.003 & 0.002 & 0.021 & 0.032 & 0.038 & 0.025 & 0.011 & 0.004 \\
\hline \multicolumn{10}{|c|}{ Pomatoschistus microps } \\
\hline Area & 0.94 & 3.09 & 0.49 & 324.64 & 45.84 & 420.41 & 152.84 & 16.86 & 3.66 \\
\hline Vol. & 0.01 & 0.02 & 0.005 & 4.67 & 0.44 & 5.26 & 1.32 & 0.09 & 0.02 \\
\hline \multicolumn{10}{|c|}{ Pleuronectes flesus postlarvae } \\
\hline Area & 1.34 & 2.27 & 26.06 & 5.04 & & & & & \\
\hline Vol. & 0.01 & 0.02 & 0.29 & 0.07 & & & & & \\
\hline \multicolumn{10}{|c|}{ Crangon crangon postlarvae } \\
\hline Area & 12.0 & 743.7 & 209.2 & 2762.9 & 100.6 & 97.2 & 611.9 & 297.8 & 26.6 \\
\hline Vol. & 0.11 & 4.99 & 2.32 & 39.75 & 0.97 & 1.22 & 5.26 & 1.61 & 0.17 \\
\hline \multicolumn{10}{|c|}{ Neomysis integer } \\
\hline Area & 585.5 & 254.5 & 434.7 & 16880.3 & 1013.0 & 247.3 & 865.8 & 917.9 & 439.0 \\
\hline Vol. & 5.45 & 1.71 & 4.83 & 242.88 & 9.74 & 3.09 & 7.46 & 4.96 & 2.74 \\
\hline \multicolumn{10}{|c|}{ Mesopodopsis slabberi } \\
\hline Area & 0.3 & 25.9 & 188.5 & 279.1 & 327.3 & 1789.2 & 23498.5 & 5177.9 & 42.6 \\
\hline Vol. & 0.00 & 0.17 & 2.09 & 4.02 & 3.15 & 22.37 & 202.57 & 27.99 & 0.27 \\
\hline \multicolumn{10}{|c|}{ Carcinus maenas } \\
\hline Area & & 0.09 & 0.14 & 9.14 & 21.85 & 17.35 & 7.00 & 7.24 & 1.03 \\
\hline Vol. & & 0.001 & 0.002 & 0.13 & 0.21 & 0.22 & 0.06 & 0.04 & 0.006 \\
\hline 1991 & $25 \mathrm{Jan}$ & $14 \mathrm{Mar}$ & $16 \mathrm{Apr}$ & $10 \mathrm{May}$ & $13 \mathrm{Jun}$ & $12 \mathrm{Jul}$ & 9 Aug & 7 Sep & $7 \mathrm{Oct}$ \\
\hline \multicolumn{10}{|c|}{ Dicentrarchus labrax } \\
\hline Area & & & & & 0.07 & 0.03 & 1.96 & 1.44 & 1.96 \\
\hline Vol. & & & & & 0.00 & 0.00 & 0.03 & 0.02 & 0.03 \\
\hline \multicolumn{10}{|c|}{ Pomatoschistus microps } \\
\hline Area & & 1.59 & 2.42 & 1.00 & 0.35 & 157.7 & 235.76 & 88.1 & 49.61 \\
\hline Vol. & & 0.02 & 0.01 & 0.02 & 0.002 & 1.75 & 3.44 & 1.47 & 0.76 \\
\hline \multicolumn{10}{|c|}{ Pleuronectes flesus postlarvae } \\
\hline Area & & 14.51 & 44.39 & 2.79 & 1.28 & & & & \\
\hline Vol. & & 0.20 & 1.95 & 0.06 & 0.01 & & & & \\
\hline \multicolumn{10}{|c|}{ Crangon crangon postlarvae } \\
\hline Area & & 0.03 & 627.4 & 51.3 & 201.0 & 52.7 & 6.3 & 0.6 & 12.9 \\
\hline Vol. & & 0.001 & 2.76 & 1.08 & 1.30 & 0.86 & 0.09 & 0.01 & 0.20 \\
\hline \multicolumn{10}{|c|}{ Neomysis integer } \\
\hline Area & 7.7 & 115.8 & 300.5 & 12.3 & 36895.7 & 3489.0 & 341.0 & 254.5 & 77.6 \\
\hline Vol. & 0.10 & 1.63 & 1.32 & 0.26 & 238.04 & 38.77 & 4.98 & 42.41 & 1.19 \\
\hline \multicolumn{10}{|c|}{ Mesopodopsis slabberi } \\
\hline Area & 0.2 & & 108.3 & 0.8 & 6621.3 & 41.3 & 5.8 & 11.5 & 55.7 \\
\hline Vol. & 0.002 & & 0.48 & 0.02 & 42.72 & 0.46 & 0.08 & 0.19 & 0.86 \\
\hline \multicolumn{10}{|c|}{ Carcinus maenas } \\
\hline Area & 0.08 & & 0.03 & 0.27 & 0.21 & 4.68 & 25.60 & 4.00 & 2.88 \\
\hline Vol. & 0.001 & & 0.001 & 0.006 & 0.001 & 0.05 & 0.38 & 0.07 & 0.04 \\
\hline
\end{tabular}

(Fig. 4). The spring months April and May 1990, the fall period August-November 1990, and January 1991 were the exceptions. Postlarval Crangon crangon were very abundant in spring and Mesopodopsis slabberi was the most important species in the autumn of 1991. The January 1991 sample consisted almost exclusively of $N$. integer and Corophium volutator. Marked peak densities of 240 ind. $\mathrm{m}^{-3}$ of $N$. integer were recorded in June 1990 and in June 1991 and to a lesser extent in September 1991. The contribution of $N$. integer to the total biomass showed the same trend. The biomass values recorded in June 1990 and 1991 exceeded $800 \mathrm{mg}$ ADW m ${ }^{-3}$.

Mesopodopsis slabberi numerically dominated the community during the autumn period of the first year when a peak density of 202 ind $\mathrm{m}^{-3}$ was recorded. This dominance was not repeated in the second year when the maximum density of $M$. slabberi coincided with the peak of Neomysis integer in June and a density of 42 ind. $\mathrm{m}^{-3}$ was reached. The biomass values for 
Table 3. Biomass estimations ( $\mathrm{mg} \mathrm{ADW} \mathrm{m}^{-3}$ ) for the most important fish and crustacean species using marsh creeks as nursery and for both mysid species

\begin{tabular}{|c|c|c|c|c|c|c|c|c|c|}
\hline 1990 & $15 \mathrm{Mar}$ & $11 \mathrm{Apr}$ & 10 May & $11 \mathrm{Jun}$ & $9 \mathrm{Jul}$ & $8 \mathrm{Aug}$ & $10 \mathrm{Oct}$ & $5 \mathrm{Nov}$ & $3 \mathrm{Dec}$ \\
\hline Dicentrarchus labrax & 5.75 & 3.56 & 1.60 & 1.66 & 0.61 & 15.85 & 23.15 & 9.53 & 6.32 \\
\hline Pomatoschistus microps & 0.95 & 2.75 & 0.81 & 18.70 & 2.22 & 31.27 & 37.55 & 3.58 & 5.60 \\
\hline $\begin{array}{l}\text { Pleuronectes flesus } \\
\text { postlarvae }\end{array}$ & 0.05 & 0.01 & 0.43 & 0.15 & & & & & \\
\hline Crangon crangon & & & & & & & & & \\
\hline postlarvae & 0.17 & 3.50 & 2.05 & 27.31 & 0.69 & 1.29 & 5.06 & 1.65 & 0.22 \\
\hline Neomysis integer & 27.82 & 10.02 & 11.71 & 843.83 & 30.19 & 7.99 & 20.59 & 9.95 & 15.27 \\
\hline Mesopodopsis slabberi & & 0.30 & 0.14 & 1.44 & 1.14 & 10.37 & 76.99 & 10.26 & 0.05 \\
\hline Carcinus maenas & & 0.15 & 0.56 & 2.44 & 9.99 & 26.81 & 88.37 & 13.72 & 4.54 \\
\hline 1991 & $25 \mathrm{Jan}$ & $14 \mathrm{Mar}$ & $16 \mathrm{Apr}$ & $10 \mathrm{May}$ & 13 Jun & $12 \mathrm{Jul}$ & 9 Aug & 7 Sep & 7 Oct \\
\hline Dicentrarchus labrax & & & & & 1.05 & 0.004 & 0.72 & 4.75 & 17.50 \\
\hline Pomatoschistus microps & & 1.16 & 0.79 & 1.80 & 0.25 & 2.47 & 16.20 & 6.90 & 27.38 \\
\hline $\begin{array}{l}\text { Pleuronectes flesus } \\
\text { postlarvae }\end{array}$ & & 1.02 & 2.75 & 0.11 & 0.04 & & & & \\
\hline $\begin{array}{l}\text { Crangon crangon } \\
\text { postlarvae }\end{array}$ & & 0.002 & 2.29 & 0.65 & 1.19 & 0.30 & 0.04 & 0.01 & 0.13 \\
\hline Neomysis integer & 0.31 & 5.32 & 7.09 & 1.06 & 817.54 & 87.91 & 10.40 & 115.62 & 2.39 \\
\hline Mesopodopsis slabberi & 0.001 & & 0.75 & 0.03 & 74.49 & 0.15 & 0.04 & 0.09 & 0.14 \\
\hline Carcinus maenas & 0.04 & & 0.62 & 1.24 & 1.58 & 3.04 & 16.65 & 15.07 & 38.59 \\
\hline
\end{tabular}
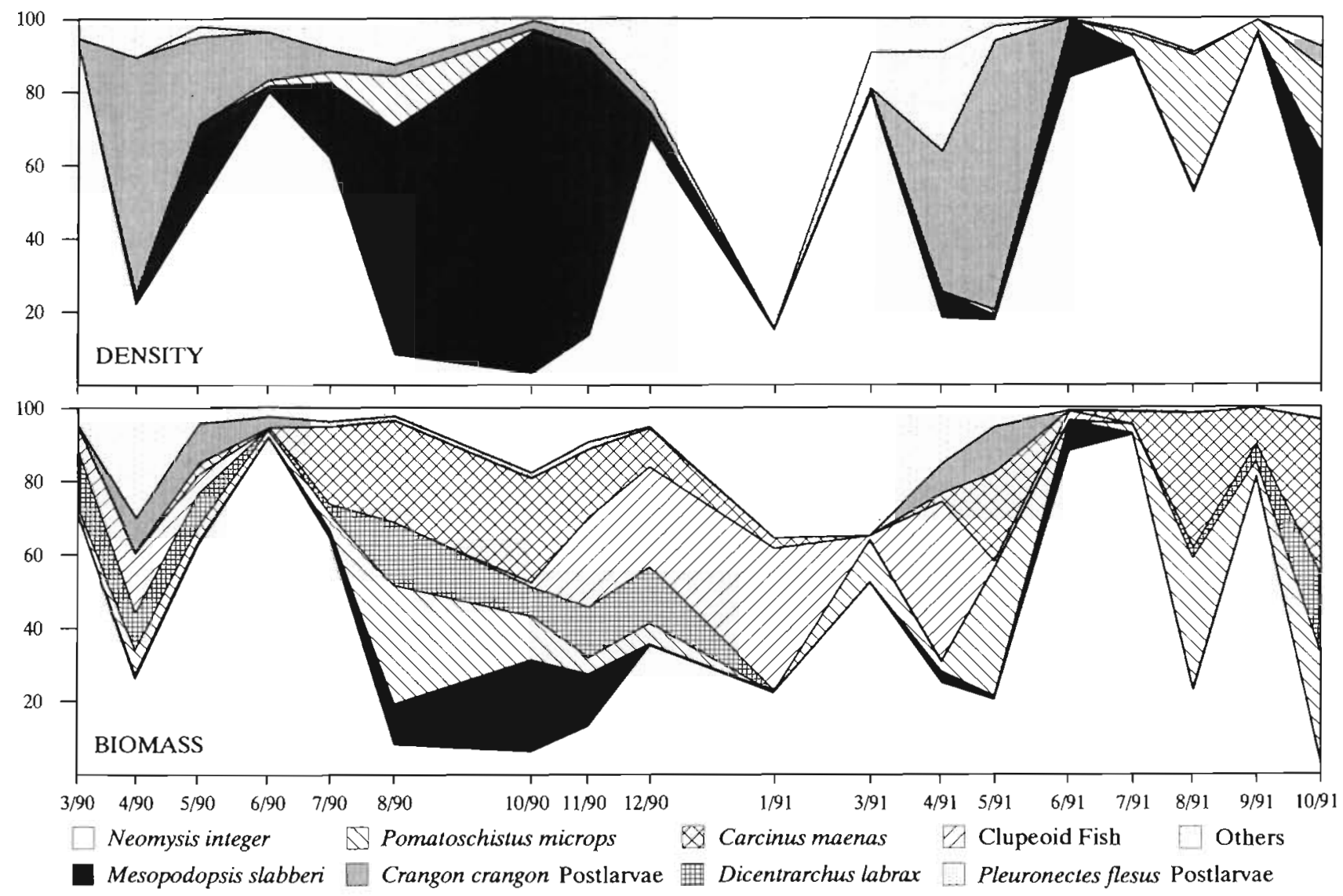

Fig. 4. Seasonal variation in relative abundance (upper panel) and relative biomass (lower panel) of the most important species. Sample dates given as month/year 
October 1990 and June 1991 were estimated to be $75 \mathrm{mg}$ ADW m $\mathrm{m}^{-3}$.

The relative numerical importance of postlarval Crangon crangon became very high during April and May when the first brood waves entered the intertidal (Fig. 4). In June 1990 we registrated a peak density of 40 ind. $\mathrm{m}^{-3}$ and a maximum biomass of $27.3 \mathrm{mg}$ ADW $\mathrm{m}^{-3}$. In the second year the densities were much lower and almost all postlarvae had left the marsh area after June. Adult or juvenile C. crangon (>10 mm SL) were only abundant in June and fall of the first year.

Juvenile shore crabs Carcinus maenas were abundant in the marsh creeks from June onwards. The mean carapace width of these juveniles was $3 \mathrm{~mm}$. By the onset of the winter all crabs were fully grown (30 mm) and had migrated out of the marsh area. The numerical importance of this species was always very low but their contribution to the total biomass was significant. Maximum densities of 0.37 ind. $\mathrm{m}^{-3}$ were found in August 1991. Biomass values had by then increased to $16.5 \mathrm{mg} \mathrm{ADW} \mathrm{m}^{-3}$.

Postlarval flounder were present in the marsh creeks in early spring but disappeared soon afterwards. The lengths of these postlarvae never exceeded $15 \mathrm{~mm} \mathrm{SL}$ and some individuals had not completely metamorphosed. Their biomass contribution to the community was negligible. Adult individuals were regularly caught but always in very low numbers. Intermediate length classes were rare.

Juvenile common gobies Pomatoschistus microps recruited in the marsh creeks from June onwards in 1990 and attained fairly high densities with maxima of almost 5 ind. $\mathrm{m}^{-3}$ (Table 2). In 1991 the first juveniles appeared a month later. In August of that year their maximum density reached only 3.5 ind. $\mathrm{m}^{-3}$. From June through October juveniles accounted for all biomass. The biomass determined in the remaining months was contributed by adults which occurred in low densities on the marsh (Fig. 4). Biomass also increased from June onwards but attained a maximum of $37.5 \mathrm{mg} \mathrm{ADW} \mathrm{m} \mathrm{m}^{-3}$ in October 1990.

Relative densities for seabass Dicentrarchus labrax were always very low in comparison to the other species. The relative biomass of this species increased as the juveniles utilised the marsh from early summer through autumn. By the beginning of the winter all young seabass had left the marsh area and probably started their migration out of the estuary. The densities attained maxima of not more than 0.03 ind $\mathrm{m}^{-3}$, and as for the common goby Pomatoschistus microps, reached comparable values in both years (Table 2). Biomass peak values were recorded in October.

Late larval and juvenile clupeoid fishes (Clupea harengus and Sprattus sprattus) were occasionally found but when present made up a large part of the total biomass.

The marsh nekton community proved to have a very consistent character. All 3 multivariate techniques identified the same simple seasonal change in community structure. The faunal assemblage apparently shifts from a spring to a summer-autumn composition. A consistent, clear winter situation could not be detected.

Samples taken in March, April and May always grouped together in both TWINSPAN analyses (Fig. 5) while the samples taken from July until November and June 1990 consistently belonged to the summer-autumn divisions. The June 1991 and January 1991 samples take a transitional place and clustered alternately within both 'seasons'. In the density plot a winter situation, containing the samples taken from October 1990 until January 1991, can be detected but in the biomass dendrogram the January sample clustered within the spring division. A likewise shift happened when considering the June 1991 sample. Postlarval Pleuronectes flesus at the first cutlevel appeared as indicator species

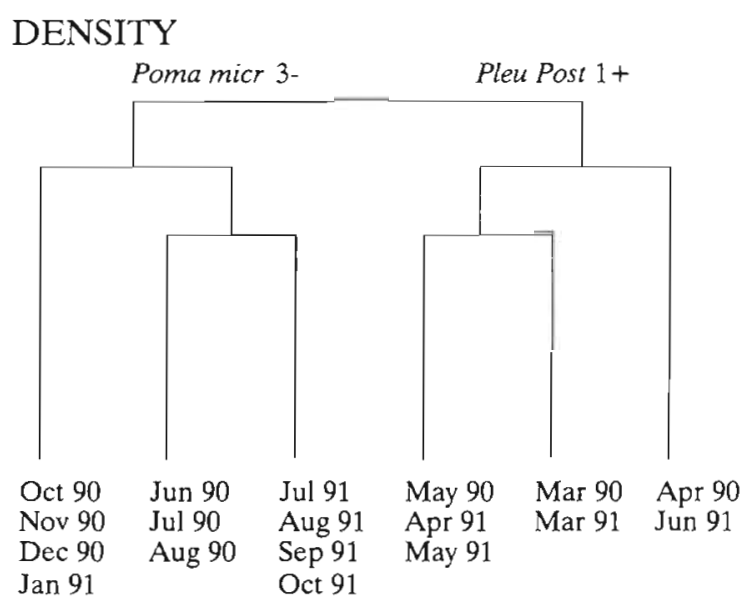

BIOMASS

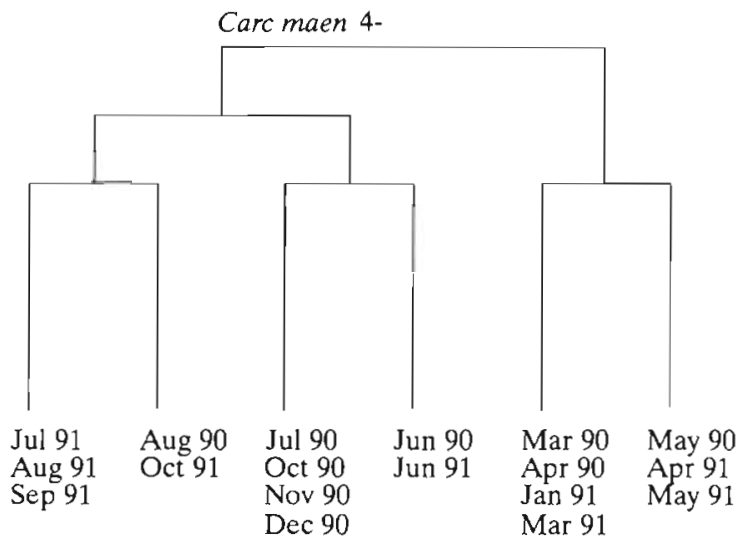

Fig. 5. TWINSPAN dendrograms for density and biomass data. Only the indicator species for the first divisions are shown 
for the spring cluster for the density data while Pomatoschistus microps at the third cutlevel was the indicator species for the summer-autumn group. Carcinus maenas at the fourth cutlevel was indicative for the summer-autumn division in the biomass dendrogram. Only the first division in both TWINSPAN dendrograms contain relevant information. The lower level divisions do not represent clear shifts in community structure. The indicator species of these subclusters are therefore not shown in the figures.

The clusters based upon the Bray-Curtis similarities revealed comparable patterns and both 'seasons' became apparent (Fig. 6). The January 1991 sample proved to have a dissimilar character. The other samples grouped as already described by the TWINSPAN results. In the density plot the December 1990 sample now clustered with the spring samples, again obscuring a clear winter situation.

The eigenvalues of the first and second axes in the CCA are quite low: 0.148 and 0.094 for the density data and 0.159 and 0.109 for the biomass data. As a consequence, the amount of variance explained by the ordination remains low: $36 \%$ for the density data and $41 \%$ for the biomass data. In the density plot (Fig. 7), temperature and salinity give large vectors but these correlate weakly with the first axis. The separation of the samples along the second axis can partly be attributed to changes in the other 3 variables measured. The vector obtained by the amount of detritus is large but only the oxygen concentration correlates well with the second axis. Water height influences the community the least, as is also evident from the biomass plot where the vectors of salinity, temperature and oxygen concentration show the same image. Here, the detritus vector correlates very well with the second axis while the vector obtained by water height is small. Both ordination plots again show a similar pattern. Species that are plotted in the vicinity of a sample are indicative for the community during that season. In the lower right quadrant of the species plot all fish species present in the marsh during springtime are grouped together. Crab larvae, only present in summer, are plotted accordingly in the left half of the graph. The plot of the sample scores emphasizes the seasonal shift in the composition of the marsh nekton community. The spring and summer-autumn communities as identified by TWINSPAN and the cluster analyses are easily recognizable in the ordination.

\section{DISCUSSION}

Net efficiency of the gear was assumed to be $100 \%$ during the complete tidal cycle. As for any other fishing gear, the catch efficiency of the stow net used in
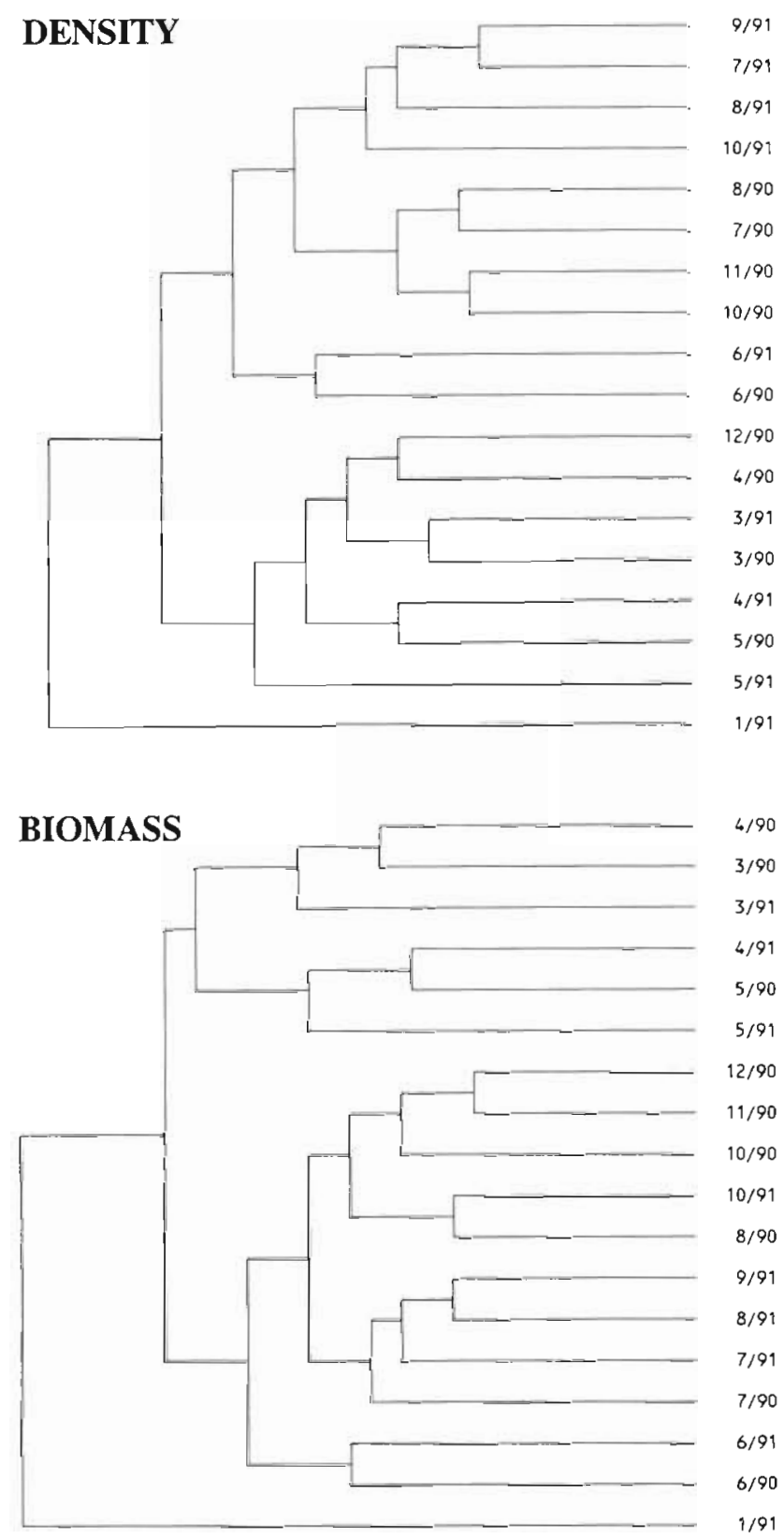

Fig. 6. Dendrograms for density and biomass data as produced by cluster analysis using Bray-Curtis similarities and group average sorting

our study is fully determined by avoidance of the gear and escapement through the meshes. The latter cause of escapement is of minor importance as our working definition of hyperbenthos includes animals larger than $1 \mathrm{~mm}$. Avoidance of the gear will be a function of the filtration efficiency and thus of the current speed. We have countered this by mathematically determining the length of our net. Given the mesh size, the diameter of the fibre, and the opening of the net one can compute the length a planktonic net should attain 
Density
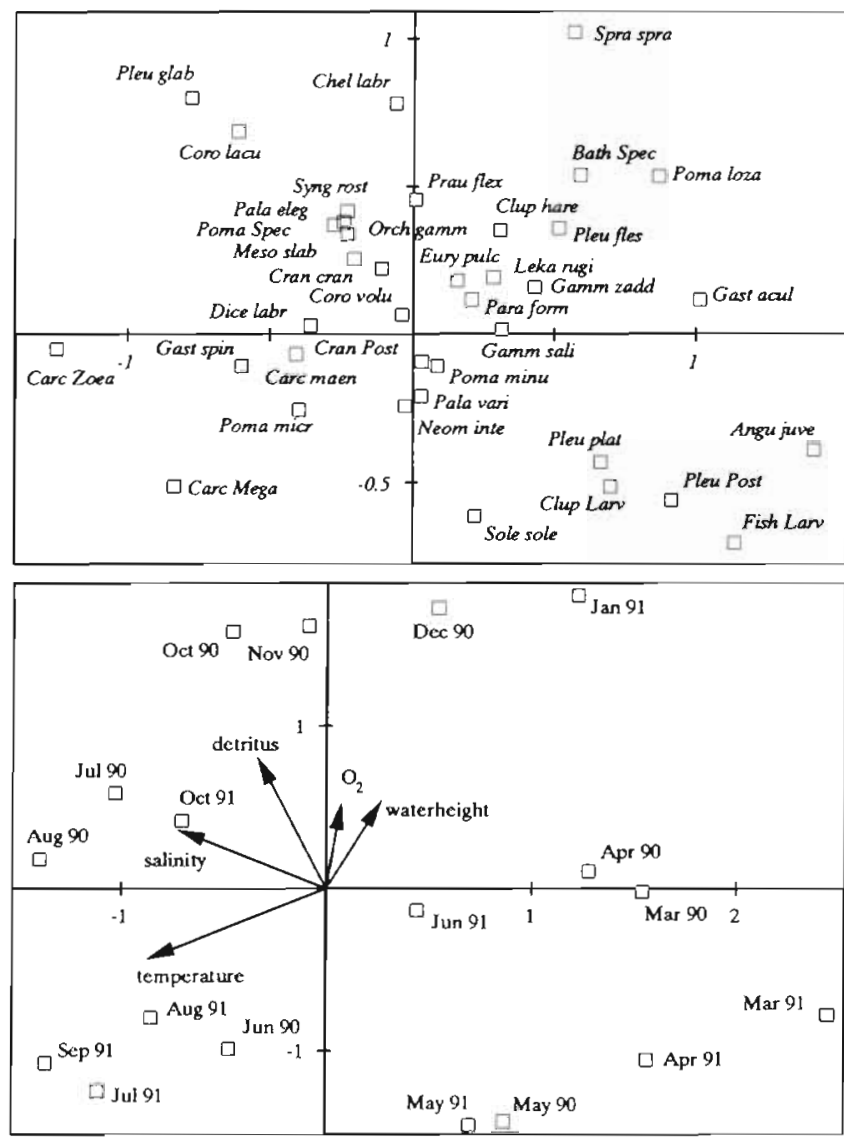

Biomass

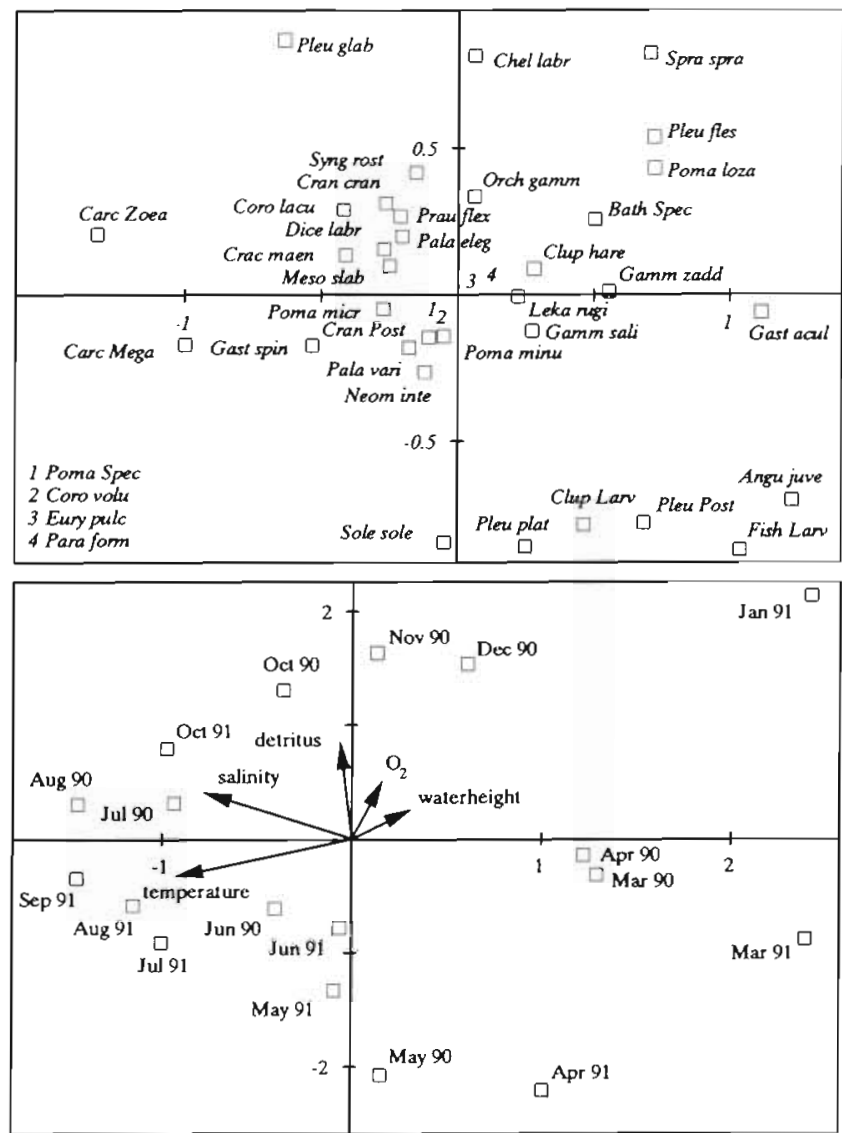

Fig. 7. Species plots (upper panels) and sample plots and environmental biplots (lower panels) obtained using CCA

in order to keep the pressure wave inside the net under all conditions (Tranter 1979). In doing so one reduces escape since the detection of the net will only then happen when the organisms are already inside of it. Especially mysids and shrimp are very sensitive to alterations of flow patterns. Clogging will definitely alter the filtration efficiency, the position of the pressure wave and, thus, the catching efficiency. We added an extra metre to the calculated length of the net in an attempt to correct for clogging with detritus. As we did not find any correlation between the amount of detritus trapped inside the net and the number of individuals caught per hour, we believe we have reached this goal. No flowmeter was installed inside the net but based upon the above we assumed the flow to be as large inside as outside the net. Escape of the gear by vision is thought to be low, though we did not measure turbidity during sampling. In the upstream part of the estuary where turbidity is high, secchi depth reaches on average only $25 \mathrm{~cm}$ (Hummel et al. 1988). In the marsh creeks visibility is further reduced through the presence of the detritus.
The marsh hyperbenthic fauna closely resembles the hyperbenthic communities present in the brackish reaches of the estuary (Mees et al. 1993b). We believe it is justified to compare the community described in this study with our data. The hyperbenthic fauna in the estuary was sampled with a towed sledge which sampled the same lower metre of the watercolumn. The net mounted on this sledge was constructed similarly as the gear used in our study and it had the same mesh size. For a comparison of the hyperbenthic mysid, amphipod and isopod faunas of both areas we refer to Mees et al. (1993a) and Cattrijsse et al. (1993). Dominant species in the hyperbenthos of this part of the estuary are Neomysis integer and Mesopodopsis slabberi. These mysids dominate the marsh community as well. The marked peak abundances of $N$. integer in June and the high densities of $M$. slabberi in summerautumn were also observed in the estuary. However, the densities showed different fluctuations in both areas. The peak abundances of these species coincided with the periods of intense reproduction as indicated by the input of a large amount of juveniles. The 
peak abundances were first observed in the marsh areas and later on in the estuary (Mees et al. 1993a). It was argued that these marshes serve as areas favoured for reproductive purposes by mysid shrimp. Preliminary results on length frequency data of $N$. integer do indicate that smaller individuals are more frequent in the marsh area than in the estuary. Some studies report the presence of mysid shrimp in tidal creeks but densities of hyperbenthic crustaceans, mysids in particular, have not been reported before for marsh areas. Mysids are thought to be very important in detritus-based food chains (e.g. the eastern part of the Westerschelde estuary; Mees \& Hamerlynck 1992). More information on the utilization of, or the dependence on, marsh habitats of these organisms would therefore be valuable.

In contrast to the hyperbenthic fauna, the epifaunal communities of estuary and marsh are less resemblant (K. Hostens unpubl.). Only few demersal fish species present in the Westerschelde proper make use of the tidal creeks. The common goby Pomatoschistus microps spends most of its life in the marsh area. It dominates the marsh fish fauna and possibly occupies a comparable niche as Fundulus heteroclitus in North American salt marshes (Kneib 1986). Flounder, another estuarine resident, also enters the creeks on a regular base. $0+$ sea bass Dicentrarchus labrax is known to frequent tidal creeks and to be fully dependent upon estuaries (Kelley 1988), Furthermore, the estuary serves as a nursery area for $0+$ sole Solea solea, $0+$ plaice Pleuronectes platessa and $0+$ common sea snail Liparis liparis but these juvenile fish never entered the creek. Sand goby Pomatoschistus minutus and Lozanoi's goby Pomatoschistus lozanoi are very abundant and important species in the estuary but were only occasionally present in the marsh. Many other juvenile fish species present in fair numbers in the estuary, like sprat Sprattus sprattus and herring Clupea harengus, are irregularly or only rarely caught in the marsh creek. Kneib (1987) and Sogard \& Able (1991) also observed that marsh creeks support higher densities for only a few species and that most species remain in adjacent (subtidal) areas. The dominance of a few species, which are regarded as generalists, is actually a general feature in studies which include marsh creeks (Cain \& Dean 1976, Weinstein \& Brooks 1983).

Several studies have already shown that salinity and temperature fluctuations have little effect on marsh nekton communities. In one of the first studies dealing with marsh nekton, Subrahmanyam \& Coultas (1980) found that less than $20 \%$ of the observed seasonal changes in species numbers and biomass was related to variations in temperature, salinity and oxygen concentration. Dramatic alterations in salinity did not influence the marsh communities studied by Weinstein et al. (1980). The same observations were made by
Rogers et al. (1984) and by Drake \& Arias (1991) who could not detect changes in nursery function of upriver areas during high freshwater discharges. These authors stated that recruitment and seasonal succession of dominants had a more profound influence than physical factors. From our data the same patterns emerge and the main difference between the spring and the summer-autumn communities is the successive appearance and disappearance of postlarval and/or juvenile stages of several species. The importance of these recruitment waves was exemplified by the TWINSPAN results. In the spring samples early postlarvae of Pleuronectes flesus are a very distinctive feature of the marsh fauna. The first division in the TWINSPAN analysis using the density data was based on the absence or presence of these small juveniles. High densities of juvenile Pomatoschistus microps and high biomasses of juvenile Carcinus maenas characterized the summer-autumn period. These recruitments can, however, not be seen independent from the increasing temperatures during spring and summer.

In contrast to our findings, Robertson \& Lenanton (1984) and Daniel \& Robertson (1990) found a positive relationship between detritus biomass and densities or biomasses of epifaunal taxa. According to these authors, the detritus, i.e. stems, shoots and leaves, reduces predation pressure and serves as food for small crustaceans. This large sized detritus did occur in our samples, but most of the particulate matter swept in and out of the Saeftinghe marsh was a brownish, peaty material, extremely fragmented and unlikely to contribute to the structural complexity of the environment. The structure of the detritus in Saeftinghe will therefore not provide refuge.

The available detritus serves as food for Neomysis integer, Mesopodopsis slabberi, isopods and amphipods. These organisms most likely enter the marsh creeks to feed upon it (Zagursky \& Feller 1985). The mysids play a major role in the detrital food chain of the eastern Westerschelde as detritivores (Mees \& Hamerlynck 1992, Hamerlynck et al. 1993). The dense aggregations of the detrital material inside the marsh creeks may attract these animals.

Most species were generally found to migrate during the first and the last hours of the tidal cycle. The average current speed observed over the tidal cycle (Fig. 2) demonstrates that migration mainly occurred when current velocities are low. Because of the absence of any correlation between the amount of detritus trapped inside the net and the number of animals caught, this migration pattern is believed not to be the result of a differential efficiency of the sampling technique used. Migration is therefore considered to be, at least partly, active. This migration pattern, in which animals tend to follow the edge of the tide, has previ- 
ously been described by Kneib (1984) for fish making use of the marsh habitat. This is not that surprising, as it is a common feature of nekton to respond to the tidal currents. These observations support the hypothesis that marshes function as foraging grounds for fish and other epifauna. Fish or shrimp species may depend upon these areas for their energy requirements (Weisberg \& Lotrich 1982) and in this sense it is beneficial to stay in the intertidal area as long as possible. Sea bass and adult flounder leaving the marsh with ebb had clearly been foraging during their stay on the marsh, as their stomachs contained significant higher amounts of food, mainly mysids and infauna organisms (Cattrijsse unpubl,; see also Kelley 1988, Raffaelli et al. 1990). Similar observations were made for common goby and postlarval shrimp. For shore crab no stomach analyses were done but crabs have been observed feeding inside marsh habitats (Ryer 1987).

Maximal abundance of sea bass, common goby and shore crab in late summer coincides with the decline of infaunal densities and biomasses in the tidal creeks. This correlation between the epifaunal and infaunal communities was observed by Subrahmanyam \& Coultas (1980). Macrobenthos data collected in a creek of another salt marsh along the estuary indicated that peak biomass and densities were found for all infauna species in August (Cattrijsse unpubl.). The most important members of the infauna were the amphipod Corophium volutator and the polychaete Nereis diversicolor. Both benthic animals are major dietary items for demersal epifauna and are heavily preyed upon by the epifauna entering the marsh creek (Cattrijsse unpubl.). Predation will not solely cause the decrease in infauna populations at the end of the summer. The high abundances of predators, especially young Pomatoschistus microps, Dicentrarchus Iabrax, Crangon crangon and Carcinus maenas, will nevertheless affect the abundance of benthos communities (Reise 1985).

Another common feature of marsh epifauna is to concentrate in pools on the marsh surface at low tide (Kneib 1984, 1987, Talbot \& Able 1984). Early postlarval flounder and brown shrimp and juvenile common goby and shore crabs were found to remain in the creek at low tide. Average densities of brown shrimp and flounder in such microhabitats were 220 and 19 ind. $\mathrm{m}^{-2}$ respectively. Juvenile gobies and shore crab did not aggregate to the same extent in pools but gobies occurred in high numbers in salt pans, higher up the marsh (pers. obs.). This behaviour can be explained as predator avoidance and supports the nursery hypothesis.

The nursery value for the investigated marsh is limited to specific life stages of only a few species. Flounder makes use of these creeks during a very short period of their early life. The lengths of the early post- larvals caught never exceeded $15 \mathrm{~mm}$ SL while juvenile length classes, very abundant in the estuary, were rarely caught in the marsh. The same early postlarval stages of sole and plaice were found on the marsh but always in very low densities. The exact reason why specifically these metamorphosing stages use the marsh is unclear. As feeding did not occur, only the predator refuge hypothesis remains valid. As any aquatic vegetation is absent in the creek and the detritus most likely does not provide shelter from predation, other structural or behavioural reasons may give refuge. Maybe the young flounders return to the estuary when metamorphosis is complete and pigmentation and their ability to hide in coarser bottoms has developed. Besides the fact that feeding did occur, the same reasons could be valid to explain the high abundance of the postlarval brown shrimp in the marsh. Juvenile thick-lipped mullet Chelon labrosus were present in autumn and juvenile thin-lipped mullet Liza ramada in spring. Both species possibly make use of the marsh creek during the early lifestages. Juvenile mullets swim close to the surface (pers. obs.) and were therefore very inefficiently sampled. The creek also functions as nursery area for the juvenile shore crabs, common goby and seabass. At this time it would be premature to quantify the nursery and foraging ground values of the Saeftinghe marsh.

The number of species using marshes as nursery can differ substantially. In Georgia, USA, Rogers et al. (1984) mention 7 species while Subrahmanyam \& Drake (1975) report 24 species utilizing Florida, USA, marshes as nursery. These differences can be caused by latitudinal effects but also regional differences may occur. Sogard \& Able (1991) and Talbot \& Able (1984) report only 4 nursling species in New Jersey, USA marshes. Rountree \& Able (1992) on the other hand mention 12 species utilizing New Jersey marshes as nursery. The pollution in the Westerschelde estuary has impoverished the fish and crustacean fauna and most former marsh areas have vanished. It will remain an open question whether both facts had their impact on the nursery use of the estuarine marshes. It is therefore hard to judge whether the Saeftinghe marsh has lost part of its nursery value for the fish or crustacean fauna of the Westerschelde estuary. Likewise research in less-polluted European estuaries fringed with marshes would prove rewarding

Acknowledgements. A.C. acknowledges a grant from the Belgian Institute for the Encouragement of Scientific Research in Agriculture and Industry, IWONL. The Netherlands Institute of Ecological Research, Centre for Estuarine and Coastal Ecology and The Dutch Ministry of Traffic, Rijkswaterstaat, Meetdienst Vlissingen gave important logistic support. The GOA 92/98-08 project of the University of Gent (Flemish Ministry of Education) and the Belgian National Science Foundation (FKFO 2.0094.92) co-financed. We thank Stichting Het 
Zeeuwse Landschap for allowing us to take samples in the marsh. Jos Van Soelen, Leon Bakx and Diedelinde Vanhooren were very helpful in the time-consuming sorting of the samples. Jan Mees, Kris Hostens and Danielle Schram voluntarily endured sampling without moaning. Special thanks go to the shepherd Joseph Cleiren who, besides being enjoyable company and serving coffee while on the marsh, helped us get away alive and in possession of our equipment during the October storm in 1991. This is contribution no. 719 of the Centre for Estuarine and Coastal Ecology.

\section{LITERATURE CITED}

Beeftink, W. G. (1966). Vegetation and habitat of the salt marshes and beach plains in the south-western part of The Netherlands. Wentia 15: 83-108

Beeftink, W. G. (1977). The coastal salt marshes of western and northern Europe: an ecological and phytosociological approach. In: Chapman, V. J. (ed.) Wet coastal ecosystems. Elsevier, Amsterdam, p. 93-121

Boesch, D. F., Turner, R. E. (1984). Dependence of fishery species on salt marshes: the role of food and refuge. Estuaries 7(4A): $460-468$

Cain, R. L., Dean, J. M. (1976). Annual occurrence, abundance and diversity of fish in a South Carolina intertidal creek. Mar. Biol. 36: 369-379

Cattrijsse, A., Mees, J., Hamerlynck, O. (1993). The hyperbenthic Amphipoda and Isopoda of the Voordelta and the Westerschelde estuary. Cah. Biol. mar. 34: 187-200

Daiber, F. C. (1982). Animals of the tidal marsh. Van Nostrand Reinhold, New York

Daniel, P. A., Robertson, A. I. (1990). Epibenthos of mangrove waterways and open embayments: community structure and the relationship between exported mangrove detritus and epifaunal standing stocks. Estuar. coast. Shelf Sci. 31 : $599-619$

de Veen, J. F., Boddeke, R., Postuma, K. H. (1979). Tien jaar kinderkamer opnames in Nederland. I Het Zeeuwse Estuarium. Visserij 32: 3-23

Dijkema, K. S., Beeftink, W. G., Doody, J. P., Gehu, J. M., Heydemann, B., Rivas Martinez, S. (1984). Salt marshes in Europe. In: Dijkema, K. S. (ed.) Nature and environment series no. 30. European Committee for the Conservation of Nature and Natural Resources, Strasbourg

Drake, P., Arias, A. M. (1991). Composition and seasonal fluctuations of the ichthyoplankton community in a shallow tidal channel of Cadiz Bay (S. W. Spain). J. Fish Biol. 39 : 245-263

Field, S. G., Clarke, K. R., Warwick, R. M. (1982). A practical strategy for analyzing multispecies distribution patterns. Mar. Ecol. Prog. Ser. 8: 37-52

Frid, C. L. J. (1988). The marine fauna of the North Norfolk salt marshes, and their ecology. Trans. Norfolk Norwich Nat. Soc. $28(1): 46-50$

Frid, C. L. J., James, R. (1989). The marine invertebrate fauna of a British coastal salt marsh. Holarct. Ecol. 12: 9-15

Hamerlynck, O., Mees, J., Craeymeersch, J., Soetaert, K., Hostens, K., Cattrijsse, A., Van Damme, P. (1993). The Westerschelde estuary; two tood webs and a nutrient rich desert. In: Nihoul, J. C. J. (ed.) Progress in Belgian oceanographic research. Institute of Marine Research and Air Sea Interaction (IRMA), Brussels, p. 217-234

Hamerlynck, O., Mees, J., Van De Vyver, P., Van Landtschoote, E., Hostens, K., Cattrijsse, A. (1990). Eindverslag Hyperbenthos onderzoek Voordelta. Rijkswaterstaat, Dienst Getijdewateren
Heip, C. (1988). Biota and abiotic environment in the Westerschelde estuary. Hydrobiol. Bull. 22: 31-34

Hemminga, M. A., Klap, V A., Van Soelen, J., Boon, J. J. (1993). Effect of salt marsh inundation on estuarine particulate organic matter characteristics. Mar. Ecol. Prog. Ser. 99: 153-161

Hill, M. (1979). TWINSPAN - a FORTRAN programme for arranging multivariate data in an ordered two-way table by classification of individuals and attributes. Cornell University, Ithaca, p. 1-60

Huiskes, A. H. L. (1988). The salt marshes of the Westerschelde and their role in the estuarine ecosystem. Hydrobiol. Bull 22(1): 57-63

Hughes, R. G. (1988). Dispersal by benthic invertebrates: the in situ swimming behaviour of the amphipod Corophium volutator. J. mar. biol. Ass. U.K. 68: 565-579

Hummel, H., Moerland, G., Bakker, C. (1988). The concomitant existence of a typical coastal and a detritus food chain in the Westerschelde estuary. Hydrobiol. Bull. 22: 35-41

Kelley, D. F. (1988). The importance of estuaries to sea bass (Dicentrarchus labrax). J. Fish Biol. 33 (Suppl. A): 25-33

Kneib, R. T. (1984). Patterns of invertebrate distribution and abundance in the intertidal salt marsh: causes and questions. Estuaries 7(4)A:392-412

Kneib, R. T. (1986). The role of Fundulus heteroclitus in salt marsh trophic dynamics. Am. Zool. 26: 259-269

Kneib, R. T (1987). Predation risk and use of intertidal habitats by young fishes and shrimp. Ecology 68(2): 379-386

Labourg, P. J., Clus, C., Lasserre, G. (1985). Résultats préliminaires sur la distribution des juvéniles de poissons dans un marais maritime du Bassin d'Arcachon. Oceanol. Acta 8(3): $331-341$

McIvor, C. C.. Odum, W. E. (1986). The flume net: a quantitative method for sampling macrocrustaceans on tidal marsh surfaces. Estuaries 9(3): 219-224

Mclvor, C. C., Odum, W. E. (1988). Food, predation risk and microhabitat selection in a marsh fish assemblage. Ecology 69(5): 1341-1351

Mees, J., Cattrijsse, A., Hamerlynck, O. (1993a). Distribution and abundance of shallow water hyperbenthic mysids (Crustacea, Mysidacea) and euphausiids (Crustacea, Euphausiacea) in the Voordelta and the Westerschelde, southwest Netherlands. Cah. Biol. mar. 34: 165-186

Mees, J., Dewicke, A., Hamerlynck, O. (1993b). Seasonal composition and spatial distribution of hyperbenthic communities along estuarine gradients in the Westerschelde. Neth. J. aquat. Ecol. 27(2-4): 359-376

Mees, J., Hamerlynck, O. (1992). Spatial community structure of the winter hyperbenthos of the Schelde estuary, The Netherlands, and the adjacent coastal waters. Neth. J. Sea Res 29(4): $357-370$

Minello, T J., Zimmerman, R. J. (1983). Fish predation on juvenile brown shrimp, Penaeus aztecus Ives: the effect of simulated Spartina structure on predation rates. J. exp. mar. Biol. Ecol. 72: 211-231

Raffaelli, D., Richner, H., Summers, R., Northcott, S. (1990). Tidal migrations in the flounder (Platichthys flesus). Mar. behav. Physiol. 16: 249-260

Reimold, R. J. (1977). Mangals and salt marshes of the eastern United States. In: Chapman, V. J. (ed.) Wet coastal ecosystems. Elsevier, Amsterdam, p. 157-166

Reise, K. (1985). Tidal flat ecology. An experimental approach to species interactions. Ecological Studies Vol. 54. Springer-Verlag, Berlin

Robertson, A. I., Lenanton, R. C. J. (1984). Fish community structure and food chain dynamics in the surfzone of sandy beaches: the role of detached macrophyte detritus. 
J. exp. mar. Biol. Ecol. 84: 265-283

Rogers, S. G., Targett, T. E., Van Sant, S. B. (1984). Fish nursery use in Georgia salt marsh estuaries: the influence of springtime freshwater conditions. Trans. Am. Fish. Soc 113: 595-606

Rountree, R. A., Able, K. W. (1992). Fauna of polyhaline marsh creeks in southern New Jersey: composition, abundance and biomass. Estuaries 15(2): 171-185

Rozas, L. P., Odum, W. E. (1988). Occupation of submerged aquatic vegetation by fishes: testing the roles of food and refuge. Oecologia 77: 101-106

Ryer, C. H. (1987). Temporal patterns of feeding by blue crabs (Callinectes sapidus) in a tidal marsh creek and adjacent seagrass meadow in the lower Chesapeake Bay. Estuaries 10(2): $136-140$

Sogard, S. M., Able, K. W. (1991). A comparison of eelgrass, sea lettuce macroalgae, and marsh creeks as habitats for epibenthic fishes and decapods. Estuar. coast. Shelf Sci. 33: $501-519$

Subrahmanyam, C. B., Coultas, C. L. (1980). Studies on the animal communities in two North Florida salt marshes. Part III. Seasonal fluctuations of fish and macroinvertebrates. Bull. mar. Sci. 30: 790-818

Subrahmanyam, C. B., Drake, S. H. (1975). Studies on the animal communities in two North Florida salt marshes. Part I. Fish communities. Bull. mar. Sci. 25(4): 445-465

Talbot, C. W., Able, K. W. (1984). Composition and distribution of larval fishes in New Jersey high marshes. Estuaries $7(4 \mathrm{~A}): 434-443$

ter Braak, C. J. F. (1988). CANOCO - a FORTRAN programme for canonical community ordination by (partial) (detrended) (canonical) correspondence analysis, princi-

This article was submitted to the editor pal components analysis and redundancy analysis (version 2.1\}. Agricultural Mat. Group, Ministry of Agriculture and Fisheries, ITI-TNO, Wageningen, p. 1-95

Tranter, D. J. (1979). Monographs on oceanographic methodology 2. Zooplankton sampling. UNESCO, Paris

Van Beek, F. A., Boddeke, R. (1990). Verspreiding en talrijkheid van garnalen (Crangon crangon L.) in het Schelde estuarium. Report DEMVIS 90-101. Institute for Fisheries Research, Ijmuiden

Van Eck, G. T. M., De Pauw, N., Van Den Langenbergh, M., Verreet, G. (1991). Emissies, gehalten, gedrag en effecten van (micro)verontreinigingen in het stroomgebied van de Schelde en Schelde-estuarium. Water 60: 164-181

Weinstein, M. P., Brooks, H. A. (1983). Comparative ecology of nekton residing in a tidal creek and adjacent seagrass meadow: community composition and structure. Mar. Ecol. Prog. Ser. 12: 15-27

Weinstein, M. P., Weiss, S. L., Walters, M. F. (1980). Multiple determinants of community structure in shallow marsh habitats, Cape Fear River estuary, North Carolina, USA. Mar. Biol. 58: 227-234

Weisberg, S. B., Lotrich, V. A. (1982). The importance of an infrequently flooded intertidal salt marsh surface as an energy source for the mummichog Fundulus heteroclitus: an experimental approach. Mar. Biol. 61: 243-246

Zagursky, G. Feller, R. J. (1985). Macrophyte detritus in the winter diet of the estuarine mysid, Neomysis americana. Estuaries 8(4): 355-362

Zijlstra, J. J. (1972). On the importance of the Wadden Sea as a nursery area in relation to the conservation of the southern North Sea fishery resources. Symp. Zool. Soc. Lond. 29: $233-258$

Manuscript first received: October 18, 1993

Revised version accepted: March 28, 1994 